\title{
APPLICATION OF A BAYESIAN APPROACH IN GIS BASED MODEL FOR EVALUATING LANDSLIDE SUSCEPTIBILITY. CASE STUDY KIMI AREA, EUBOEA, GREECE
}

\author{
Ilia I. ${ }^{1}$, Tsangaratos P. ${ }^{2}$, Koumantakis I. ${ }^{3}$, Rozos D. ${ }^{4}$ \\ ${ }^{1}$ National University of Athens, School of Mining and Metallurgical Engineering, Department of Geology, \\ Laboratory of Engineering Geology and Hydrogeology, Iroon Polytecheiou, 15780, Zografou, Greece, \\ gilia@metal.ntua.gr \\ ${ }^{2}$ National University of Athens, School of Mining and Metallurgical Engineering, Department of Geology, \\ Laboratory of Engineering Geology and Hydrogeology, Iroon Polytecheiou, 15780, Zografou, Greece, \\ ptsag@metal.ntua.gr \\ ${ }^{3}$ National University of Athens, School of Mining and Metallurgical Engineering, Department of Geology, \\ Laboratory of Engineering Geology and Hydrogeology, Iroon Polytecheiou, 15780, Zografou, Greece, \\ mmgski@central.ntua.gr \\ ${ }^{4}$ National University of Athens, School of Mining and Metallurgical Engineering, Department of Geology, \\ Laboratory of Engineering Geology and Hydrogeology, Iroon Polytecheiou, 15780, Zografou, Greece, \\ rozos@metal.ntua.gr
}

\begin{abstract}
The purpose of this study is to present a Bayesian approach (weight-of-evidence method) that utilizes GIS and employs statistical analysis in defining the main factors contributing to the occurrence of landslides in Kimi, Euboea, Greece and to calculate the probability for future landslide manifestation. Landslide locations were identified from field surveys and interpretation of aerial photographs. Additional data were collected from various sources (topographic, geological, land cover maps etc.) and introduced into a spatial database using GIS technology. The above data sources have been used to generate various thematic data layers that have been resample to $20 \times 20 \mathrm{~m}^{2}$ grid size. Applying the developed methodology it was possible to generate appropriate susceptibility map and thus to predict areas of instability. The results of the analysis were verified using the landslide location data, showing a satisfactory agreement between expected and existing data on landslide location. The outcomes could be used to reduce associated hazards, and to plan land use construction.
\end{abstract}

Key words: Weight of evidence, Bayesian approach, landslide susceptibility, GIS.

\section{Introduction}

The prediction and mitigation of geological hazards are consider the most critical part for urban development, as they represent a threat, the direct and indirect results of which affect the economic and social issue of any community. Among geological hazards, landslide phenomena constitute the most frequent one and pose a serious problem especially when manifested in populated areas.

However, due to the complexity and variability of the causative and triggering factors, the evaluation of landslide phenomena often produces outcomes characterized by high uncertainty. 
In recent years the development of numerous methods, which employs the use of Geographic Information Systems (GIS), have been able to express the hazard and susceptibility of landslide manifestation, providing cost and time effective tools for evaluating the most critical slope sites (Carrara et al, 1991, Guzzeti et al. 1999, Dai et al, 2002, Chung and Fabbri 2003, Lee et al, 2004, Rozos et al. 2008), producing less uncertain results. GIS-based models are capable to capture, store, manipulate, analyze and display diverse sets of spatial and non-spatial data, but also to integrate appropriate engineering models (Babu \& Mukesh, 2002) during evaluation of related engineering problems, such as landslide.

The Weight of Evidence methodology presented in this study follows a similar approach in order to evaluate landslide phenomena. It's a quantitative method which has been adapted to GIS applications in the 1980's to map mineral potential, combining evidence in support of a hypothesis (Kemp et al., 1999, Raines et al., 2000). Although originally designed for non-spatial application, the method can be also used for spatial predictions when the target is the probability of point occurrences (Kemp et al., 1999). The method has been recently used in evaluating landslide susceptibility using GIS techniques (Lee et al, 2002, Mathew et al, 2007, Bettian et al, 2007).

In this paper, the effectiveness of the method has been tested in Kimi, an area experienced substantial landslide events, where a well documented and formulated database exists (Ilia et al, 2008). The database allowed the utilization of GIS technology and probability analysis in defining the main factors contributing to the occurrence of landslides events, and also calculating the probability for future landslide manifestation. Thus the produced landslide susceptibility map will identify zones of varying degree of instability based on the estimated significance of the causative factors, regardless of the time factor. Moreover, this map will be an efficient supporting tool used by decision makers in urban planning and regional land development.

\section{Study area}

\subsection{Geological settings}

Euboea, is the second largest island of Greece (after Crete) and the third largest island of the Eastern Mediterranean. Geographically, it is located eastern of Attica and extends along the eastern coast of Greece. Geologically, in Euboea Island outcrop three tectonic units (Katsikatsos et al. 1986).

In Euboea, the 'Pelagonian Unit', the northern part of the island is occupied by non-metamorphic rocks. The southern part of the Island is covered by high-pressure/low-temperature rocks named 'South Euboea Blueschist Belt', the northern extension of the intermediate level Cycladic Blueschist Unit. Under these rocks in central Euboea, the para-autochthonous 'Almyropotamos Unit' outcrops in a tectonic window. This unit, which is composed of Mesozoic-Eocene sediments, pertains to the external part of the Hellenides (Dürr et al. 1978) and is considered to have experienced only lowpressure metamorphism (Shaked et al. 2000).

The Kimi-Aliveri basin, which has been selected as the study area, was formed in the Early Miocene. This basin was filled by conglomerates and marls of 500m thick, with lignite intercalations, which was later intruded by volacnic rocks (Katsikatsos 1976, Pe-Piper \& Piper 1994). In the southern margin of this basin, conglomerates, with a thickness of $1000 \mathrm{~m}$, of late Miocene in age (Katsikatsos et al. 1981) were accumulated.

More analytically as presented by a previous study (Koumantakis et al, 2008, Ilia et al, 2008) we can find (Figure 1): 


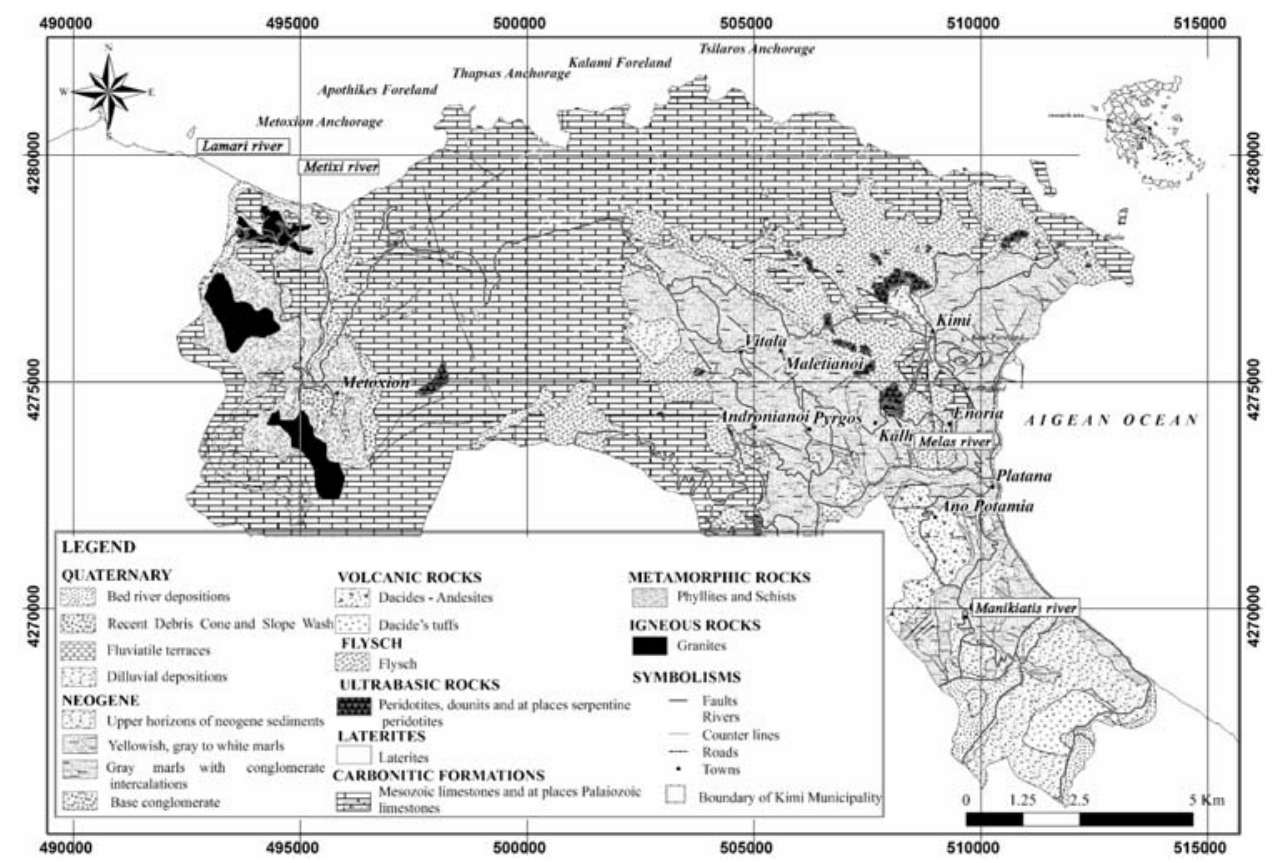

Fig. 1: Geological Map of Kimi Municipality.

- The Quaternary deposits presented in the study area, consist of bed river deposits, debris and slope wash, as well as of fluviatile terraces and dilluvial depositions.

- The Upper horizons of neogene sediments are constituted by conglomerate alternations and clayey marls. Grits, gravels and pebbles are of volcanic origin and their size varies from 2 $-4 \mathrm{~cm}$.

- The Base conglomerate presents medium to low cohesiveness. Volcanic rocks are presented in the south - eastern department of the Municipality of Kimi with dacides - andesites.

- Flysch formation is constituted by alternations of clayey schists, sandstones, conglomerates and limestones.

- Ultrabasic rocks consist of peridotites, dounits and at places serpentine peridotites. Lateritic are plotted in the western part of Kimi basin.

- Carbonitic formations are presented with Mesozoic, and at places, Palaiozoic limestones. Palaiozoic phyllites and schists, occur usually high cracked and weathered with high weathering.

- Granites are presented in the Western part of Kimi basin, in Carboniferous age.

\subsection{Climatic features}

The climatic features in a region, in relation with the nature of the rock and the slope inclinations, are thought to be crucial factors, with regard to all kinds of failures in the geological formations. The infiltrated water, in conjunction with the seasonal and daily temperature fluctuations, produces a relaxation of the coherence of the rock formations that often leads to landslide manifestation. For the assessment of the climatic features, all monthly rainfall, temperature and humidity data taken from the Kimi station of the Meteorological Service ( $221 \mathrm{~m}$. altitude), have been exploited. The analysis 
showed that the mean annual temperature for the period $1956-1989$ is $16^{\circ} \mathrm{C}$, while January is the coldest month with an average monthly temperature of $8,6^{\circ} \mathrm{C}$, February with $8,5^{\circ} \mathrm{C}$, December and March with $10^{\circ} \mathrm{C}$. July is the warmer month, with an average monthly temperature of $24,9^{\circ} \mathrm{C}$. The average annual humidity in the station of Kimi, is $61.7 \%$. The monthly average during the dry season is close to $50 \%$, while during the period from October to February the humidity range from 66 to $70 \%$. The predominant wind direction is north. Finally, the average annual amount of rainfall is $1071 \mathrm{~mm}$, but in highland zones of the region, the annual amount of rainfall is expected to be higher.

\section{Data and Methodology}

The applied methodology uses the Weight of Evidence probabilistic model, based on the Bayes theorem and on the concepts of prior and posterior probability, to determine if the given specifications (a set of independent variables) results in unstable or stable slopes (dependent variable). The main objective is assessing the spatial relationship between the distribution of the areas affected by landslides, known landslide locations, and the distribution of the analyzed landslide susceptibility variables, evidential themes. It is therefore possible to calculate the degree of influence that each variable had, but also the degree of influence it will have in the future, regarding the manifestation of landslide events.

As it is obvious this approach implies that future landslides occur under conditions and factors similar to those acted in the past, and such behaviour will remain constant over time. It also implies that the factors should be conditionally independent from each other regarding the occurrence of landslide events, an assumption that should be checked excluding depended factors from subsequent analysis.

In an area which contains a number of instability sites (L), the prior probability of slide occurrence per unit area, is calculated as the total number of slides observed in the past, under similar conditions over the total area (A).

$$
P\{L\}=\frac{N\{L\}}{N\{A\}}
$$

Having a set of evidence data, which could be thought as landslide-influenced factors, the prior probability could be modified and addressed as conditional or posterior probability $\mathrm{P}\{\mathrm{L} \mid \mathrm{B}\}$, expressing the probability that an event $(\mathrm{L})$ will occur under the presence or the absence of an evidence $\mathrm{B}$,

$$
P\{L \mid B\}=\frac{P\{L \cap B\}}{P\{B\}}=P\{L\} \times \frac{P\{B \mid L\}}{P\{B\}}
$$

and

$$
P\{L \mid \bar{B}\}=\frac{P\{L \cap \bar{B}\}}{P\{\bar{B}\}}=P\{L\} \times \frac{P\{\bar{B} \mid L\}}{P\{\bar{B}\}}
$$

For mathematical reasons, the conditional probabilities can be expressed more conveniently as odds:

$$
\mathrm{O}=\mathrm{P} / 1-\mathrm{P}
$$

Therefore, the above equations are modified as:

$$
O\{L \mid B\}=O\{L\} \times \frac{P\{B \mid L\}}{P\{B \mid \bar{L}\}}
$$


and

$$
O\{L \mid \bar{B}\}=O\{L\} \times \frac{P\{\bar{B} \mid L\}}{P\{\bar{B} \mid \bar{L}\}}
$$

, where $\mathrm{O}\{\mathrm{L} \mid \mathrm{B}\}$ and $\mathrm{O}\{\mathrm{L} \mid \bar{B}\}$ are the posterior odds of a landslide event (L), given the presence or the absence of an evidence (B).

Bonham-Carter (1994) defined positive and negative weights for the evidence (B) $\left(\mathrm{W}^{+}\right.$and $\left.\mathrm{W}^{-}\right)$giving information about whether there is a positive or a negative correlation between the evidence and the landslide locations that combine those conditional probabilities as:

$$
\begin{aligned}
W^{+}= & \ln \frac{P\{B \mid L\}}{P\{B \mid \bar{L}\}}, \text { when the evidence (B) is present and } \\
W^{-}= & \ln \frac{P\{\bar{B} \mid L\}}{P\{\bar{B} \mid \bar{L}\}},
\end{aligned}
$$

If there are $\mathrm{N}$ evidence factors, then the weights can be summed up to find the natural logarithm of the posterior odds of the potential slide sites as given by:

$$
\ln O_{\text {posterior }}\{L\}=\sum_{i=1}^{n} W_{i}+\ln O_{\text {prior }}\{L\}
$$

Another measure of the spatial association between the landslide event (L) and the evidence (B) is provided through the magnitude of contrast $\mathrm{C}$, which is determined by the difference, $W^{+}, W^{-}$. When $\mathrm{C}$ is positive it implies positive correlation and when it is negative it implies negative spatial association. This means that if more events (landslides) occur within an evidence layer that would be expected by chance, the $\mathrm{W}^{+}$is positive and the $\mathrm{W}^{-}$is negative. Conversely, $\mathrm{W}^{+}$is negative and $\mathrm{W}$ - is positive where fewer events occur within an evidence layer than would be expected by chance (Bonham-Carter et al. 1989).

The studentized value of $C$ is calculated as the ratio of $C$ to its standard deviation $S(C), C / S(C)$, and serves as a guide to the significance of the spatial association, acting as a measure of the relative certainty of the posterior probability (Bonham-Carter 1994).

To run successfully the proposed methodology, a well structured spatial database which contains data, concerning landslide locations, in digital format, such as geological maps, topographic characteristics, infrastructure networks and many more features, are required. All the landslide-related factors which are to be used in the analysis were rasterized, converted to cells, and introduced in the GIS system. Slope failures were presented as points, so each set of variables could be presented on a simple thematic map, with binary pattern, showing stable and unstable cells. As a first step, the probability that a landslide would occur if evidence is present or absent was calculated for each of the above evidence layers. For each cell the final probability was the sum of contrasts of each variable, as above mentioned.

The model was built up using a Training Data set, consisting of about $85 \%$ of the entire landslide events and a landslide susceptibility map was produced. The remainder $15 \%$, Testing set of data, was 
used in order to validate the model. The distinction of the database into training and test data has been done randomly, in order to guarantee that both are random samples from the same distribution.

\section{Generating evidence layers}

There are no specific criteria or guidelines for selecting the parameters to include in the developed model. However, the general idea is a) the independent variables should have a certain relation to the dependent variable, b) to vary spatially, c) to be expressed in a measurable scale, and d) its effect should not account for double consequences in the final result (Ayalew \& Yamagishi, 2004). In the study area, the main triggering factor is the high amount of precipitation and in some extent tectonic activity. However those two factors have been excluded from the model since the objective was to produce landslide susceptibility map and to identify zones of varying degree of instability based on the estimated significance of the causative factors have, regardless of the time factor and any triggering factor.

Having in mind the above mentioned, lithology, altitude, slope inclination, slope orientation and road network proximity, are include in the model as causative factors responsible for landslide manifestation. These factors form the necessary evidence layers that the method needs. A brief description of each of the evidence layers and the spatial distribution of landslide events are given below:

The model requires landslide location data introduced in the GIS system as a point shapefile. A total of 72 landslides locations of various dimensions were identified and mapped in the whole area of the Municipality of Kimi. A detailed examination of the affected area with field observations along with the interpretation of aerial photographs was helpful in order to construct a landslide database contain data from various sources of information.

Lithology is considered as one of the most causative parameter regarding the landslide manifestation throughout Greece. The large surface development of formations appearing in cyclothematic sequences, such as schist-chert formations, flysch sediments, Molassic and Neogene deposits with anisotropic geomechanical behaviour facilitate the manifestation of abundant slope failures (Koukis and Rozos, 1982, Koukis, 1988). In the studied area landslide events mainly took place at the upper horizons of the Neogene marls and flysh formations, which were mainly covered by thick weathering mantle.

The altitude of a site is a combined result of the tectonic activity and the erosion - weathering processes and is related to climatic conditions through an interactive influence. Thus, altitude is indirectly contributing to the slope failure manifestation.

The inclination of a slope along with the orientation plays a significant role in the concept of landslide manifestation as a causative factor (Rozos et al, 2008). It seems that such behaviour is controlled by the combined influence of many variables, such as the intensity and severity of climatic conditions, the weathering processes, the type and density of vegetation cover, as well as the discontinuity pattern and internal geometry of the geological formations (Huma and Radulescu, 1978, Carrara 1983, 1984, Maharaja, 1993). In addition certain orientations are associated by increased snow concentration, higher erosion and intense wreathing process as the climatic agents facilitate the cyclic alteration of dry and wet periods. In the study area, those orientations were the NNW-NNE $\left(315^{0}-45^{\circ}\right)$ and SE-SW $\left(135^{0}-225^{\circ}\right)$.

Finally it has been observed that many landslides occur close to the road network. The slope instability could be caused either by the uncontrolled or controlled blasting and widening of the roads, or by the loss of support due to removal of material from the lower portion of the slopes during road widening. The continuous data have been converted to a binary pattern, using buffer zones in order 
to identify a statistical correlation between road proximity and landslide locations.

Each one of the above mentioned factors was introduced in GIS system providing the necessary evidence thematic layers in digital format, producing grid files with cell size $20 \times 20 \mathrm{~m}$, appropriate for statistical and probabilistic analysis. The classification followed for each factor was based on expert knowledge and bibliographical reference (Rozos et al, 2008, Ilia et al, 2008).

\subsection{Checking for conditional independency}

As already mentioned the Weight of Evidence method in order to be applied successfully assumes conditional independency among the landslide-influenced factors and that the population of each factor has a normal distribution. To calculate such independency, $\chi^{2}$ (chi-square) method was used. The first step in computing the Chi-squared statistic is the computation of the contingency table, which is set up for each pair using as reference points the landslide locations. The number of observed landslide locations in each cell of the table is compared with the expected. The assumption of conditional independence is tested by determine if the measured $\chi^{2}$ value exceeds or not a theoretical $\chi^{2}$ value, given by the number of degrees of freedom and the level of significance. In Table 3 the results of Chi-squared statistic are showed, implying that each of the analyzed variables should be included in the model since the assumption of conditional independency among them is true. For example it can be seen that the pairs of slope inclination and slope orientation shows a conditional independency, since the theoretical $\chi^{2}$ value, shown in the table in brackets, is 26.217 at the $99 \%$ significance level (degree of freedom $=8$ ) and the calculated $\chi^{2}$ value was 20.226. This implies that those predictor variables could be used together for the calculation of landslide susceptibility map, since the null hypothesis of independence is true.

\section{Results and discussion}

The accuracy of the outcomes depends mostly on the amount and quality of available data, the working scale and the selection of the appropriate analysis and modelling. The process of creating those thematic layers, involves several qualitative or quantitative approaches (Soeters and van Westen, 1996, Aleotti and Chowdhury, 1999; Guzzetti et al., 1999). As mentioned by Bonham-Carter (1994), the results of the Weight of Evidence method, are strongly dependent on the number of events in-

Table 1. Chi-square statistics.

\begin{tabular}{|c|c|c|c|c|c|}
\hline Parameters & Lithology & $\begin{array}{c}\text { Slope } \\
\text { orientation }\end{array}$ & $\begin{array}{c}\text { Slope } \\
\text { inclination }\end{array}$ & Altitude & $\begin{array}{c}\text { Road } \\
\text { Proximity }\end{array}$ \\
\hline Lithology & - & $27,903(32,00)$ & $11,55(26,217)$ & $11,152(37,566)$ & $5,297(20,090)$ \\
\hline $\begin{array}{c}\text { Slope } \\
\text { orientation }\end{array}$ & - & $20,226(26,217)$ & $6,085(37,566)$ & $6,215(20,090)$ \\
\hline $\begin{array}{c}\text { Slope } \\
\text { inclination }\end{array}$ & & - & $6,357(30,578)$ & $10,235(16,812)$ \\
\hline $\begin{array}{c}\text { Altitude } \\
\text { Road } \\
\text { Proximity }\end{array}$ & & & - & $5,5767(23,209)$ \\
\hline
\end{tabular}


Table 2. Weight of Evidence analysis between landslide-events and factors.

\begin{tabular}{|c|c|c|c|c|c|c|c|c|}
\hline No & Road Proximity & $\mathbf{W}^{+}$ & $s-W^{+}$ & $\mathbf{W}^{-}$ & $s-W^{-}$ & C & S-c & c/s-c \\
\hline 1 & $0-100 \mathrm{~m}$ & 1.309 & 0.2858 & -0.666 & 0.037 & 1.976 & 0.256 & 7.713 \\
\hline 2 & $100 \mathrm{~m}-200 \mathrm{~m}$ & 0.6789 & 0.0666 & -0.146 & 0.021 & 0.852 & 0.297 & 2.782 \\
\hline 3 & $200 m-300 m$ & 0.64827 & 0.0833 & -0.108 & 0.02 & 0.7566 & 0.321 & 2.354 \\
\hline 4 & $>300 \mathrm{~m}$ & 0 & 3.71E-06 & 0.978 & 0.016 & -0.9775 & 0.127 & -7.695 \\
\hline No & Lithology & $\mathbf{W}^{+}$ & $\mathbf{s}-\mathbf{W}^{+}$ & $\mathbf{W}^{-}$ & $s-W^{-}$ & $\mathbf{C}$ & S-c & S-c \\
\hline 1 & Class 1 & $-2,367$ & 0,333 & 0,677 & 0,016 & $-3,045$ & 0,591 & $-5,144$ \\
\hline 2 & Class 2 & 0 & 0 & 0,010 & 0,016 & $-0,010$ & 0,127 & $-0,079$ \\
\hline 3 & Class 3 & $-1,287$ & 0,500 & 0,091 & 0,016 & $-1,379$ & 0,718 & $-1,919$ \\
\hline 4 & Class 4 & 1,224 & 0,032 & $-0,534$ & 0,032 & 1,759 & 0,254 & 6,924 \\
\hline 5 & Class 5 & 0,692 & 0,038 & $-0,308$ & 0,027 & 1,001 & 0,257 & 3,890 \\
\hline No & Slope inclination & $\mathbf{W}^{+}$ & $s-W^{+}$ & $\mathbf{W}^{-}$ & $s-W^{-}$ & $\mathbf{C}$ & S-c & S-c \\
\hline 1 & $0-17^{\circ}$ & 0,127 & 0,023 & $-0,224$ & 0,050 & 0,352 & 0,271 & 1,297 \\
\hline 2 & $17^{\circ}-36^{\circ}$ & $-0,154$ & 0,052 & 0,076 & 0,023 & $-0,231$ & 0,275 & $-0,838$ \\
\hline 3 & $36^{\circ}-50^{\circ}$ & $-0,994$ & 1,00 & 0,028 & 0,016 & $-1,023$ & 1,008 & $-1,015$ \\
\hline 4 & $>500$ & 0 & 0 & 0,002 & 0,016 & $-0,003$ & 0,127 & $-0,021$ \\
\hline No & Slope aspect & $\mathbf{W}^{+}$ & $\mathbf{s}-\mathbf{W}^{+}$ & $\mathbf{W}^{-}$ & $s-W^{-}$ & $\mathbf{C}$ & S-c & c/s-c \\
\hline 1 & $225^{\circ}-275^{\circ}$ & $-1,382$ & 1,000 & 0,050 & 0,016 & $-1,433$ & 1,008 & $-1,421$ \\
\hline 2 & $45^{\circ}-90^{\circ}$ & $-0,168$ & 0,100 & 0,035 & 0,019 & $-0,204$ & 0,345 & $-0,592$ \\
\hline 3 & $\begin{array}{l}90^{\circ}-135^{\circ}, \\
275^{\circ}-315^{\circ}\end{array}$ & $-0,240$ & 0,090 & 0,060 & 0,019 & $-0,301$ & 0,332 & $-0,904$ \\
\hline 4 & $\begin{array}{c}3150-450 \\
1350-225^{\circ}\end{array}$ & 0,217 & 0,025 & $-0,303$ & 0,045 & 0,521 & 0,265 & 1,962 \\
\hline No & Altitude & $\mathbf{W}^{+}$ & $\mathbf{s}-\mathbf{W}^{+}$ & $\mathbf{W}^{-}$ & $s-W^{-}$ & $\mathbf{C}$ & S-c & c/s-c \\
\hline 1 & $0-220 \mathrm{~m}$ & 0,672 & 0,023 & $-0,707$ & 0,050 & 1,380 & 0,271 & 5,079 \\
\hline 2 & $220-440 \mathrm{~m}$ & 0,024 & 0,062 & $-0,008$ & 0,021 & 0,033 & 0,290 & 0,114 \\
\hline 3 & $440-660 \mathrm{~m}$ & $-1,002$ & 0,250 & 0,126 & 0,017 & $-1,130$ & 0,516 & $-2,185$ \\
\hline 4 & $660-880 \mathrm{~m}$ & 0 & 0 & 0,163 & 0,016 & $-0,164$ & 0,127 & $-1,287$ \\
\hline 5 & $880-1100 \mathrm{~m}$ & 0 & 0 & 0,069 & 0,016 & $-0,069$ & 0,127 & $-0,546$ \\
\hline 6 & $>1100 \mathrm{~m}$ & 0 & 0 & 0,008 & 0,016 & $-0,009$ & 0,127 & $-0,070$ \\
\hline
\end{tabular}

troduced in the model (e.g., on the estimation of probabilities) and on the quality of the landslide inventory map. Therefore, probabilities are very low if the area is characterized by rare events, and the results have to be cautiously interpreted. Applying the Weight of Evidence method, the spatial rela- 


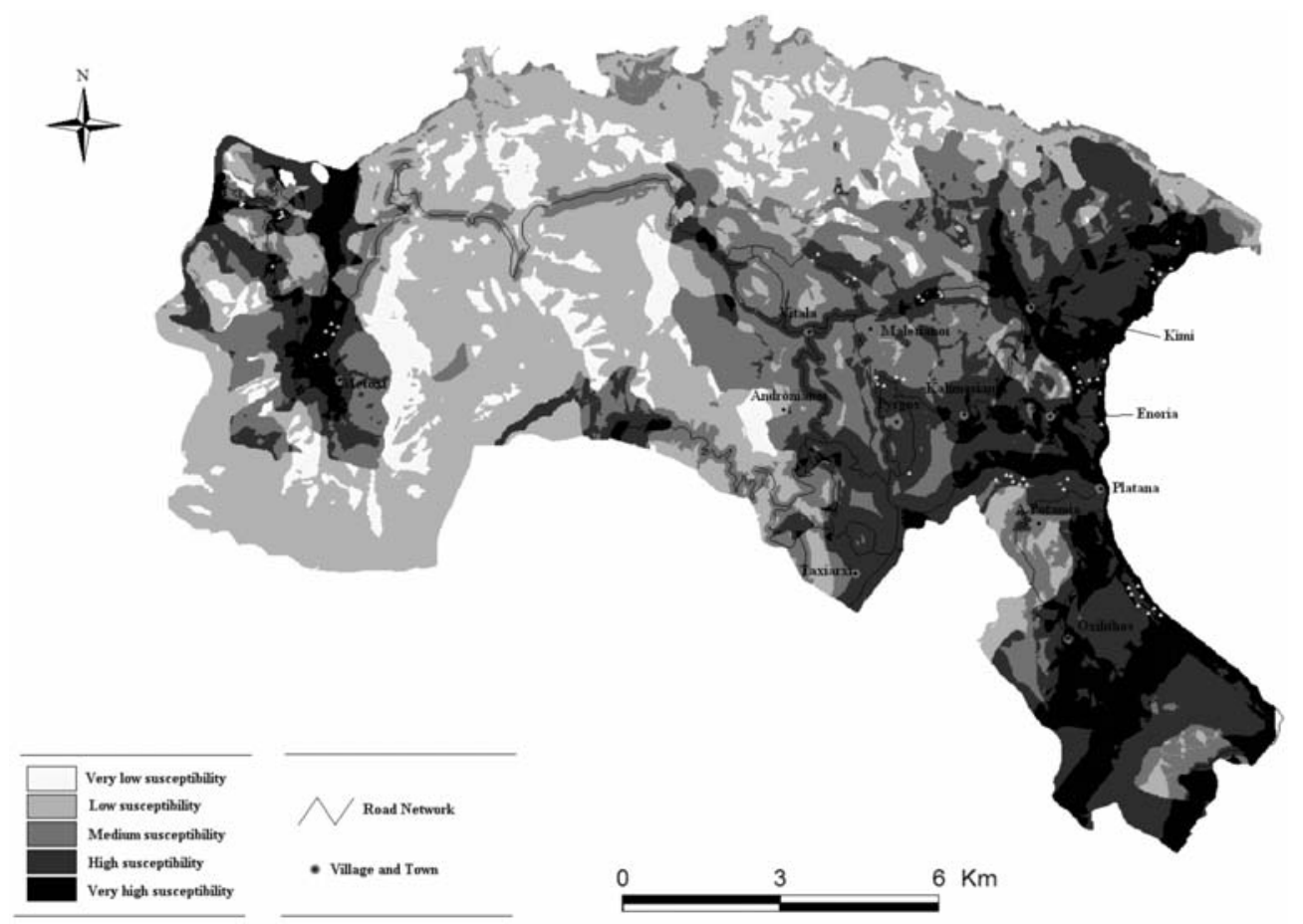

Fig. 2: Landslide Susceptibility map of Kimi municipality area

tionship and the contrast value between landslide-occurrence location and each of the variables were extracted. Table 2 shows in detail the landslide-influenced factors in which we could find the positively correlated with the landslide locations, and supposed to be significant causative factors that are likewise possible indicators for landslide manifestation.

$$
L s i=\sum_{i=1}^{n} C_{i}
$$

The contrasts of each factor type were summed up to calculate the landslide susceptibility index (Lsi), as shown in the following equation, and by applying Spatial analysis techniques within GIS, a susceptibility landslide map is obtained (Figure 2).

Calculating the area, each class occupied by using only the Training set of data, the $8.45 \%$ of the studied area was classified as having very low susceptibility index, $36.48 \%$ was classified as having low susceptibility index, $21.76 \%$ was classified as having medium susceptibility index, $21.68 \%$ was classified as having high susceptibility index and $11.62 \%$ was classified as having very high susceptibility index. To validate the developed model, control points were used. Those control points are past landslide events that have not been included in the model, and are used as Test Data set. As already mentioned, about $15 \%$ (10 landslide event, randomly distributed through the study area), where used to determine the Prediction rate. The three first classes, very low, low and medium susceptibility, include about $10 \%$ of the Test data set, while the $90 \%$ percent of the landslides where found in the areas of high and very high susceptibility index. The produced prediction rate $(90 \%)$ was based on the random distributed control points and was accepted as satisfied. 


\section{Conclusion}

In the presented study, the Weight of Evidence method was introduced in order to define the main factors contributing to the occurrence of landslides in Kimi, Euboea, Greece and to calculate the probability for future landslide manifestation. The results were used to produce a Landslide Susceptibility Map indicating areas of very low, low, medium, high, and very high susceptibility.

The analysis performed using the Weight of Evidence, proved that this method could be thought as an objective system that can discriminate the various parameters, in order to understand the importance of each one of them, in the development of landslide phenomena. It is also capable to calculate the weights, separately for each study area, allowing the selection of different weights, for the same parameters, when different settings exist. This process is an objective one and almost independent by the choices of the user.

The statistical method employed in this study determined several crucial factors for landslide susceptibility in the study area. Among them, slopes with angles from $0^{\circ}$ to $17^{\circ}$ facing NNW-NNE $\left(315^{0}-45^{\circ}\right)$ or $\left(135^{0}-225^{\circ}\right)$ SE-SW, consisting of Quaternary and Neogene sediments, located within a distance of $100 \mathrm{~m}$ from the road network and with altitude value less than $220 \mathrm{~m}$ were identified as indicators for high slope instability.

\section{References}

Aleotti P, Chowdhury, R., 1999. Landslide hazard assessment: summary, review and new perspectives. Bull Eng Geol Environ 58:21-44.

Ayalew, L. and Yamagishi, H., 2004. Slope movements in the Blue Nile basin, as seen from landscape evolution perspective, Geomorphology 57, pp. 95-116.

Babu Sivakumar, G. L. and Mukesh M. D., 2002. Characterization of soil spatial variability and its influence on slope stability, Indian Geotechnical Journal, 32(2), 123-145.

Bettian, N. and Birgit, T., 2007. Landslide susceptibility assessment using "weights-of-evidence" applied to a study area at the Jurassic escarpment (SW-Germany). Geomorphology 86, 12-24.

Bonham-Carter, G.F., Agterberg, F.P., Wright, D.F., 1989. Weights of evidence modelling: A new approach to mapping mineral potential. Statistical Applications in Earth Sciences 89(9), 171-183.

Bonham-Carter, G.F., 1994. Geographic information systems for geoscientists: Modelling with GIS. Pergamon Press, Canada, 398.

Carrara,A., 1983. Multivariate models for landslide hazard evaluation: Mathematical Geology, v. 15, no. 3, p. 403-426.

Carrara, A., 1984. Landslide hazard mapping: aims and methods, Mouvements de Terrains, Association Francaise Géographie Physique. Colloque de CAEN, pp. 141-151.

Carrara, A., Cardinali, M., Detti, R., Guzzetti, F., Pasqui, V., Reichenbach, P., 1991. GIS techniques and statistical models in evaluating landslide hazard, Earth Surface Processes \& Landforms, Volume 16, Issue 5, 427-445.

Chung, C.F. and Fabbri, A.G., 2003. Validation of spatial prediction models for landslide hazard mapping. Natural Hazards, 30: 451-472.

Dai, F.C. and Lee, C.F., 2002. Landslide characteristics and slope instability modeling using GIS, Lantau Island, Hong Kong, Geomorphology, Volume 42, Issue 3-4, 213-228.

Dürr, S. T.-Altherr, R.-Keller, J. Okrusch, M. Seidel, E., 1978. The median Aegean crystalline belt: Stratigra- phy, Structure, Metamorphism, Magmatism. In Alps, Apennines, Hellenides, 455-477.

Guzzeti, F. Carrara, A., Cardinali, M., Reichenbach, P., 1999. Landslide hazard evaluation: a review of 
current techniques and their application in a multi-scale study, central Italy, Geomorphology 31, pp. 181-216.

Huma, I., Radulescu, D., 1978. Automatic production of thematic maps of slope stability. Bull IAEG 11(17):95-99.

Ilia, I., Koumantakis, I., Rozos, D., Markantonis, K., Tsagaratos, P., 2008. Landslide Phenomena in Kimi area, Evia Island, Central Greece. Geophysical Research Abstracts, Vol. 10, EGU2008-A-06831, 2008 SRef-ID: 1607-7962/gra/EGU2008-A-06831 EGU General Assembly 2008.

Katsikatsos, G. 1976. La structure tectonique de Attique et de leile de Euboe. Bull Soc Gool France 19 : 211-228.

Katsikatsos, G., De Bruijn, H., Van der Meulen, A. J., 1981. The Neogene of the island of Euboea (Evia): a review. Geol Mijnb 60 : 509-516.

Katsikatsos, G., Migiros, G., Triantaphyllis, E. \& Mettos, A., 1986. Geological structure of internal Hellenides (E. Thessaly SW Macedonia, Euboea Attica Northern Cyclades and Lesvos). I.G.M.E., Geol. and Geoph. Res., Special issue, 191-212.

Kemp, L. D., Bonham-Carter, G. F., Raines, G. L., Looney, C.G., 1999. Arc-SDM: A review extension for Weight of Evidence Mapping, http://gis.nrcan.gc.

Koukis, G. and Rozos, D. (1982). Geotechnical conditions and landslide movements in the Greek territory in relation to the geological structure and geotectonic evolution. Mineral Wealth, 16: 53-69.

Koukis, G., 1988. Peloponnesus: History, Geology and Engineering Geology aspects. Proceedings Int. Symposium on the Engineering Geology of Ancient Works, Monuments and Historical sites, Marinos \& Koukis (eds), Greece, 4, 2213 - 2234, Athens, Greece.

Lee ,S., Choi, J., Min, K., 2002. Landslide susceptibility analysis and verification using the Bayesian probability model, Environmental Geology, Volume 43, 120-131.

Lee ,S., Ryu, J-H., Won, J-S., Park, H-J., 2004. Determination and application of the weights for landslide susceptibility mapping: using an artificial neural network. Engineering Geology. v71. 289-302.

Koumantakis, I., Rozos, D., Markantonis, K., Ilia, I., Tsagaratos, P., 2008. Landslide Phenomena of Kimi Municipality. Research Program founded by the Prefecture of Euboea Island.

Mathew J., Jha V., Rawat G., 2007. Weights of evidence modelling for landslide hazard zonation mapping in part of Bhagirathi valley, Uttarakhand, Current Science, Vol. 92, no5, 628-638.

Maharaja, R. 1993. Landslide processes and landslide susceptibility analysis from an upland watershed: a case study from St.Andrew, Jamaica, West Indies. Engineering Geology, Vol. 34, pp. 53-79.

Pe-Piper, G. and Piper, D.J.W., 1994. Miocene magnesian andesites and dacites, Evia, Greece: adakites associated with subducting slab detachment and extension. Lithos, 31, 125-140.

Raines, G. L., Bonham-Carter, G. F., Kemp, L., 2000. Predicting probabilistic modeling using Arcview GIS. Arcuser, April June 2000, p.45-48.

Rozos D., Pygiotis, L., Skias, S., Tsagaratos, P., 2008. An implementation of rock engineering system for ranking the instability potential of natural slopes in Greek territory. An application in Karditsa County. Landslides, Vol. 5 no3, 261-270.

Shaked Y., Avigad D. \& Garfunkel Z. 2000. Alpine high-pressure metamorphism at the Almyropotamos window (southern Evia, Greece). Geol. Mag., 137, 367-380.

Soeters, R. and van Western, C.J., 1996. Slope instability recognition, analysis, and zonation. In: A.K. Turner and R.L. Schuster, Editors, Landslides: Investigation and Mitigation, Special Report vol.247, Transportation Research Board, National Academy Press, Washington, D.C. (1996). 